How to cite this article:

Tanveer, Z., \& Jamil, M. (2019). The impact of dividend announcement on stock returns among the ten top companies in Pakistan. Malaysian Management Journal, Vol. 23(December), 47-64.

\title{
THE IMPACT OF DIVIDEND ANNOUNCEMENT ON STOCK RETURNS AMONG THE TEN TOP COMPANIES IN PAKISTAN
}

\author{
ZUBAIR TANVEER* \\ Punjab Economic Research Institute \\ Lahore, Pakistan \\ MUHAMMAD JAMIL \\ School of Economics \\ Quaid-i-Azam University, Islamabad
}

*Corresponding author: zubair.tanveer@peri.punjab.gov.pk

\begin{abstract}
The study tested the response of stock prices around the dividend declaration dates in Pakistan stock exchange. It estimated the data of 1110 dividends announced by 91 firms of the highest ten active sectors of Pakistan Stock Exchange. To empirically investigate the relationship between stock returns and dividend announcement, the panel regression was employed by creating dummy variables for 61 days around the dividend declaration dates. Cumulative average abnormal returns and average abnormal returns were also estimated around the events with the help of event study methodology. Outcomes of the empirical analysis revealed strong evidence of market abuse in the term of insider trading and supported the argument of the information content hypothesis and semistrong form of efficient market. Moreover, the study also found a robust impact of the probable ex-dividend date. The study recommended that it is a responsibility of stock exchange regulatory authorities, whistleblowers, registered companies, and the investors collectively to detect and punish this white-collar financial crime.
\end{abstract}


Keywords: Dividend announcement, dividend irrelevance hypothesis, event study methodology, stock returns.

\section{Introduction}

The private entities aim to maximise their profits irrespective of their market structure. Public limited companies distribute dividend to its shareholders. Dividend is defined as the cost of equity capital to equity shareholders (Mehndiratta \& Gupta, 2010). The dividend policy is the disbursement plan made by the board of directors of the corporation to decide the volume and type of payment given to the investors on their shares. Khan (2012) stated that investors are sensitive regarding dividend as it is a source of income for them and a tool to assess the performance of a corporation. Further, the announcement of dividends has different impact on share price of companies of different sectors wherein insider trading also influences the share prices. In this perspective, it would be important to investigate the impact of dividend announcement and inside trading on share prices of top ten sectors of Pakistan Stock Exchange (PSX).

Miller and Modigliani (1961) presented the policy irrelevance hypothesis which states that, in perfect markets and perfect information, it is the investment decision rather than the dividend which exerts an impact on share values. However, Gordon (1963) argued that dividend has a significant impact on share prices. Lintner (1956) provided the foundation for the dividend signaling theory which states that the behavior of the managers indicates to investors with a signal of increase in dividend which develops positive perception among the investors about forthcoming prospects of the investment. Similarly, the "information content of dividends" theory assumes that managers have more information than investors and dividend is a source of reducing asymmetric information among them. Correspondingly, the tax clientele effect (Baker, 2009) explained that as capital gain faces less tax than the ordinary income tax levied on dividend, it is better for a firm to reduce the dividend to increase the overall value of shares. However, the corporations still announce dividends which has become a puzzle and enigma for financial economists.

There are several factors like bonus issue, stocks split, rights issue and dividends which influence share prices directly and indirectly identified by various studies (Ahmed \& Javid, 2008; Chaudhary, Hashmi \& Younis, 
2016; Mahmood, Sheikh \& Ghaffari. 2011; Mehndiratta \& Gupta, 2010; Mukora, 2013; Ngoc \& Cuong, 2016; Nishat \& Irfan, 2004; Rajamohan \& Muthukamu, 2014; Rosario \& Chavali, 2016).

The first research question of the current study is whether dividend announcements have a significant impact on the prices of the stocks of the top ten active sectors of PSX. The other research query is to check whether insider trading exists on the event of dividend announcement. This investigation would be valuable in financial economics as it will provide practical conclusions on the relationships of dividend policy and the performance of top active sectors of PSX.

Although there are many other studies that have been conducted in Pakistan, however, there is no study that has used the panel regression analysis with dummy variables around the dividend announcement dates and event study methodology by taking daily data with such a large sample size of top ten active sectors of PSX. Moreover, the study has computed short term, medium term and long term event windows as well as also constructed two estimated windows for the analysis which is clearly a novel contribution in the empirical work of this area.

\section{Literature Review}

Some studies such as Aharony and Swary (1980), Asquith and Mullins (1983), Venkatesh (1989) and Mukora (2013) found a direct association between dividends and stock returns. Moreover, the results of Below and Johnson (1996) supported the doctrine of information content hypothesis (ICH) that dividend conveys useful information to the investors. Habibullah and Baharumshah, (1999) and Abdullah, Rashid and Ibrahim (2002) also examined the efficient market hypothesis and ICH in Kuala Lumpur Stock Market (KLSE). Similarly, Sanda, Shafie and Gupta (2002) used a random walk hypothesis to investigate the behaviour of stock prices in KLSE. Saleh (2007) also provided evidence for the insider trading and leakages of information.

Rajamohan and Muthukamu (2014), Majanga (2015), and Sharif, Purohit and Pillai (2015) proved that the dividends had the strongest impact on stock prices. Rosario and Chavali (2016) narrated that the post-event average abnormal returns (AAR) and cumulative average abnormal returns (CAAR) had a significant pattern in Oman stock exchange. Jahfer (2016) and Ngoc and Cuong (2016) also provided evidence for dividend signaling 
theory in Vietnam and Colombo Stock Exchange, respectively. Similarly, the outcome of Swarnalatha and Babu's (2017) and Ozo and Arun's (2019) studies confirmed the signaling hypothesis as well. However, the results of the studies by Uddin and Uddin (2014) and Khurana and Warne (2018) were in favour of the dividend irrelevant hypothesis. Likewise, in the Dhaka Stock Market, Khan (2019) did not find the relationship between dividend announcements and stock returns. On the other hand, Kadıoğlu, Telçeken and Öcal (2015) analysed the tax-clientele effect in the Turkish Stock Exchange and stated that dividend announcements negatively related to stock price due to the higher tax rates on cash dividend relative to the capital gain. Nevertheless, Poornima, Morudkar, and Reddy (2019) found positive and negative impacts of dividend announcements on returns of private and public banks respectively with the help of event study methodology and panel regression model.

In the stock markets of Pakistan, Nishat and Irfan (2004), Nazir, Nawaz, Anwar and Ahmed (2010), Khan (2012) as well as Chaudhary et al. (2016) examined the behavior of share price volatility around the dividend announcements. Ahmed and Javid (2008) documented that current earnings and past dividends played a key role in smoothing the dividend strategy, and other variables like the concentration of investors, liquidity, size, leverage, profitability and investment prospects had a significant impact on dividend plan. The outcome of the Akbar and Baig (2010) revealed efficiency in semistrong form, as well as Mahmood et al. (2011), documented the prevalence of insider trading in the Karachi Stock Exchange (KSE), Pakistan.

\section{Methodology}

There are many techniques available in the literature to estimate the impact of a specific event on stock prices. Authors like Chaudhary et al. (2016), Mahmood et al. (2011), Mehndiratta and Gupta (2010), Mukora (2013), and Rosario and Chavali (2016) applied event study methodology (ESM) to examine the responsiveness of a stock's value relative to the event. Similarly, Nazir et al. (2010), Kadığlu et al. (2015) and Sharif et al. (2015) calculated the reaction of share prices regarding different market variables using the random effects and fixed effects models. The present study has used both the ESM and panel regression analysis. Under the rationality of the market, the ESM is very much appreciated to capture the sensitivity of the share prices because Campbell and MacKinlay (1997) declared that event studies offer an idyllic instrument for investigating the information content of the disclosures and this methodology in extensively used for the empirical analysis. 


\section{Steps of Event Study Methodology}

The initial step of the ESM is to identify the event. In our study, we treat the dividend announcement date as an event. After choosing the event, the ESM has the following steps:

\section{Specify the Estimation Window}

The estimation window is the time that is chosen before the event date to estimate the coefficients through Ordinary Least Squares (OLS) and these coefficients are then used to calculate the excess or abnormal return during the event window. Campbell and MacKinlay (1997) and Mahmood et al. (2011) recommended that the estimation window for each event can be 250 days and -21 to -270 days before an event, respectively. Peterson (1989) stated that for studies comprise daily data, the ideal length for the estimation window is from 100 to 300 days. However, Pynnoonen (2005) was in favour of a 120-days estimation window. The present study has used two estimation windows, the first is for 100 days and the second is for 300 days before the announcement. The logic behind using these two estimation windows is to estimate the parameters based on the minimum and maximum length ${ }^{1}$.

\section{Calculating Normal Returns for Stock and Market}

The study takes daily data of closing price for the top ten active ${ }^{2}$ sectors of PSX from $3^{\text {rd }}$ January 2000 to $11^{\text {th }}$ September 2017 . The formula to calculate the normal return is given by Equation (1).

$$
R_{i t}=\ln \left(\frac{P_{i t}}{P_{i t-1}}\right)
$$

where $R_{i t}$ symbolises the normal return for the firm $i$ during time $t, P_{i t}$ indicates the closed prices of the company $i$ during time $t$ and $P_{i t-1}$ represents the lagged value of the stock. For the calculation of market return, KSE-100 index is used as a benchmark using Equation (2).

$$
R_{m t}=\ln \left(\frac{P_{m t}}{P_{m t-1}}\right)
$$

where $R_{m t}$ represents market returns for the period $t, P_{m t}$ indicates the closing price of the KSE-100 index during time $t$, and $P_{m t-1}$ denotes its lagged value.

\section{Estimating Abnormal Returns}

Abnormal Returns (AR) are the deviation of the actual return from its expected or mean value. So, AR for the event windows have also been estimated. The 
event windows are constructed around events like the declaration of dividend dates. Peterson (1989) declared that for daily data, the researchers may use 21 to 121 days as event windows. Rosario and Chavali (2016) created 39 days event window $( \pm 19)$, Chaudhary et al. (2016) made event window for \pm 7 days (15 days) and Mahmood et al. (2011) generated an event window for 51 days $(-20,+30)$ to analyse the behaviour of stock prices. Some studies like Mukora (2013), and Rajamohan and Muthukuma (2014) created an event window for 61 days $( \pm 30)$.

The present study has constructed $15( \pm 7), 31( \pm 15)$ and 61 days $( \pm 30)$ event windows to investigate the short, medium and long term impact of dividend announcement on stock returns, respectively. Gunasekarage and Power (2006) used three trading days for the short run and 20 trading days in the long run. Similarly, Mehndiratta and Gupta (2010) constructed $( \pm 30)$ days for long-run analysis.

So, to calculate estimated returns, OLS technique on Equation (3) has been applied.

$$
R_{i t}=\alpha_{i}+\beta_{i} R_{m t}+\varepsilon_{i t}
$$

where $R_{i t}$ means normal returns of a firm $i$ during time $t$ and $R_{m t}$ denotes returns of the KSE-100 index for time $t$. The parameters $\alpha_{i}$ and $\beta_{i}$ are calculated using the OLS technique. In the given model, the assumption is that the disturbance term is independently and identically distributed having zero mean and constant variance. The period for this regression is the length of the estimation window. The estimated normal returns $\left(\hat{R}_{i t}\right)$ are then used to get abnormal returns shown by Equation (4).

$$
A R_{i t}=R_{i t}-\hat{R}_{i t}
$$

$A R_{i t}$ in Equation (4) represents abnormal returns of $i$ stock for time $t, \hat{R}_{i t}$ and $R_{i t}$ are expected and actual returns respectively. Campbell and MacKinlay (1997) stated that the market model is an efficient model to extract the influence of an event because it eliminates the proportion of the variation in the stock prices which relates to the variation in the market index. Therefore, the difference of actual normal returns to expected returns is pure, which may help to notice the impact of the event on the share price.

\section{Measuring the Average Abnormal Return}

To clarify whether the dividend announcement has a significant impact on the stock returns, we must generate cumulative average abnormal returns 
(CAAR) as well as average abnormal returns (AAR). The formula for AAR is given in Equation (5).

$$
A A R_{t}=\frac{1}{N} \sum_{i=1}^{N} A R_{i t}
$$

where shows abnormal returns and $N$ is the number of the events. This AAR is generated for event windows, i.e. for 15 days event window ( \pm 7 days) where is the event date. Similarly, other event windows consist of 31 days $( \pm 15)$ and 61 days ( \pm 30 days).

\section{Measuring Cumulative Average Abnormal Returns}

CAAR is calculated for every given event window $(15,31$ and 61 days) to analyse the behaviour of returns around the event. The method of computing of CAAR is as follows.

$$
C A A R_{t}=\sum_{t=1}^{N} A A R_{t}
$$

where $N$ is the time span of event window.

\section{Statistical Tests}

The last step of the ESM is to check whether the estimated values of AAR and CAAR are statistically significant or not. For this purpose, the researchers use different tools like Z-test and t-test. The popular t-statistic was used by Brown and Warner (1980), Kadıoğlu et al. (2015), Mahmood, et al. (2011), Mukora (2013), Ngoc and Cuong (2016), Rosario and Chavali (2016), and Uddin and Uddin (2014). The null hypothesis $\left(\mathrm{H}_{0}\left(\mathrm{H}_{0}\right)\right.$ is that is there no significant change occurring in stock prices around the dividend announcement date.

The formula for -test is written as:

$$
t=\frac{A A R_{t} \text { or CAAR }}{\text { Standard Deviation }}
$$

Estimated t-test's value would be compared with. If $\mathrm{H}_{0} t$-value is larger then, is rejected.

\section{Panel Data Analysis}

The core advantage of the panel data technique is the investigation of the heterogeneity in cross sections and time units. This analysis has more freedom 
and reliability because of the combined observations of each cross section. The present study used fixed effects and random effects models. Pynnonen (2005) suggested the following models for the event analysis.

$$
\begin{aligned}
& R_{i t}=\alpha+\beta_{1} D B A_{i t}+\beta_{2} D A A_{i t}+\mu_{i t} \\
& R_{i t}=\alpha+\beta_{1} D B A_{i t}+\beta_{2} D A A_{i t}+\beta_{3} T i_{1}
\end{aligned}
$$

where $R_{i t}$ is daily returns of stock $i$ during period $t, D B A$ and $D A A$ are dummies for before and after the dividend announcement, respectively. The time variable is used for trend, $\alpha$ and $\beta_{1}$. are coefficients, and $\mu_{i t}$ is the error term.

\section{Data and Variables}

For this study, top ten active sectors out of 35 sectors of PSX have been considered for the analysis. These sectors were nominated at the PSX's website on $26^{\text {th }}$ October 2017. These sectors include Engineering (ENGR), Commercial Banks (BANK), Textile Composite (TEXT), Cable and Electrical Products (CAEP), Food and Personal Care Products (FPCP), Technology and Communication (TECH), Cement (CMNT), Fertiliser (FRTZ), Chemical (CHEM) and Oil \& Gas Marketing Companies (OGMC).

The rationale behind the selection of top active sectors based on their turnover rate is that the top active sectors announce dividends frequently. Another criterion is the selection based on the capitalisation. However, there might be the problem of activeness (profit) of the stocks as it could be possible that with a massive capital, the sector may not be acting well, and resultantly, incapable of giving a dividend to its shareholders.

\section{Table 1}

Top Ten Active Sectors of the Pakistan Stock Exchange Limited

\begin{tabular}{lccccc}
\hline Sectors & $\begin{array}{c}\text { Turnover } \\
(\%)\end{array}$ & $\begin{array}{c}\text { Capital } \\
\text { (Billion RS.) }\end{array}$ & $\begin{array}{c}\text { Total } \\
\text { companies }\end{array}$ & $\begin{array}{c}\text { Number of } \\
\text { companies }^{3}\end{array}$ & $\begin{array}{r}\text { Number of } \\
\text { announcements }^{2}\end{array}$ \\
\hline ENGR & 14.4 & 167.060 & 8 & 8 & 76 \\
BANK & 12.0 & 1414.769 & 23 & 8 & 147 \\
TEXT & 11.2 & 220.211 & 56 & 24 & 180 \\
\hline & & & & (continued)
\end{tabular}




\begin{tabular}{lccccc}
\hline Sectors & $\begin{array}{c}\text { Turnover } \\
(\%)\end{array}$ & $\begin{array}{c}\text { Capital } \\
\text { (Billion RS.) }\end{array}$ & $\begin{array}{c}\text { Total } \\
\text { companies }\end{array}$ & $\begin{array}{c}\text { Number of } \\
\text { companies }^{3}\end{array}$ & $\begin{array}{r}\text { Number of } \\
\text { announcements }\end{array}$ \\
\hline CAEG & 7.9 & 53.102 & 8 & 3 & 36 \\
FPCP & 7.0 & 829.551 & 12 & 11 & 153 \\
TECH & 6.8 & 103.767 & 4 & 2 & 50 \\
CMNT & 6.8 & 530.374 & 21 & 11 & 109 \\
FRTZ & 5.1 & 515.574 & 7 & 5 & 104 \\
CHEM & 4.4 & 294.141 & 21 & 15 & 190 \\
OGMC & 3.9 & 362.551 & 8 & 4 & 65 \\
\hline
\end{tabular}

For this study, the data on the closed prices of each stock, KSE-100, and dates of dividend declaration are taken from the business recorder's and PSX's website for the period between January 2000 and September 2017. The descriptive statistics of each sector are given in Table 1.

\section{Results and Discussion}

\section{Results Based on the Panel Regression Model}

For the econometric analysis, the study divides the panel regression into two models based on Equations (8) and Equation (9) ${ }^{4}$. The results of the random effects and fixed effects models for both equations are presented in Table 2. The results reveal that the dividend declaration has no substantial impact on the stock prices in both models for all sectors.

The value of the coefficient of the post-announcement dummy in Table 3 depicts that the BANK, TEXT, CAEP, TECH, and CMNT sectors have a substantial impact of the announcement on their prices. However, ENGR, FPCP, FRTZ, CHEM and OGMC sectors are in favour of the dividend irrelevance hypothesis due to insignificant values of the dummies. In contrast to the post event dummy, the value of the parameter of the pre-announcement dummy is only significant for commercial and chemical sectors which is an evidence of insider trading in these sectors.

Moreover, for the suitability of the models, the study indicates that the outcomes of the Hausman test with the null hypothesis is that the random effects model is more fitting than fixed effects model. If the value of $X^{2}$ is significant or probability, given in parenthesis, is less than 5 percent then we can reject. RE model in favor of FE model. The estimated statistics of the Hausman test, in Table 2 and Table 3, reveals that fixed effects model is suitable for almost all the given regression analysis. 
Malaysian Management Journal Vol. 23, December 2019 47-64

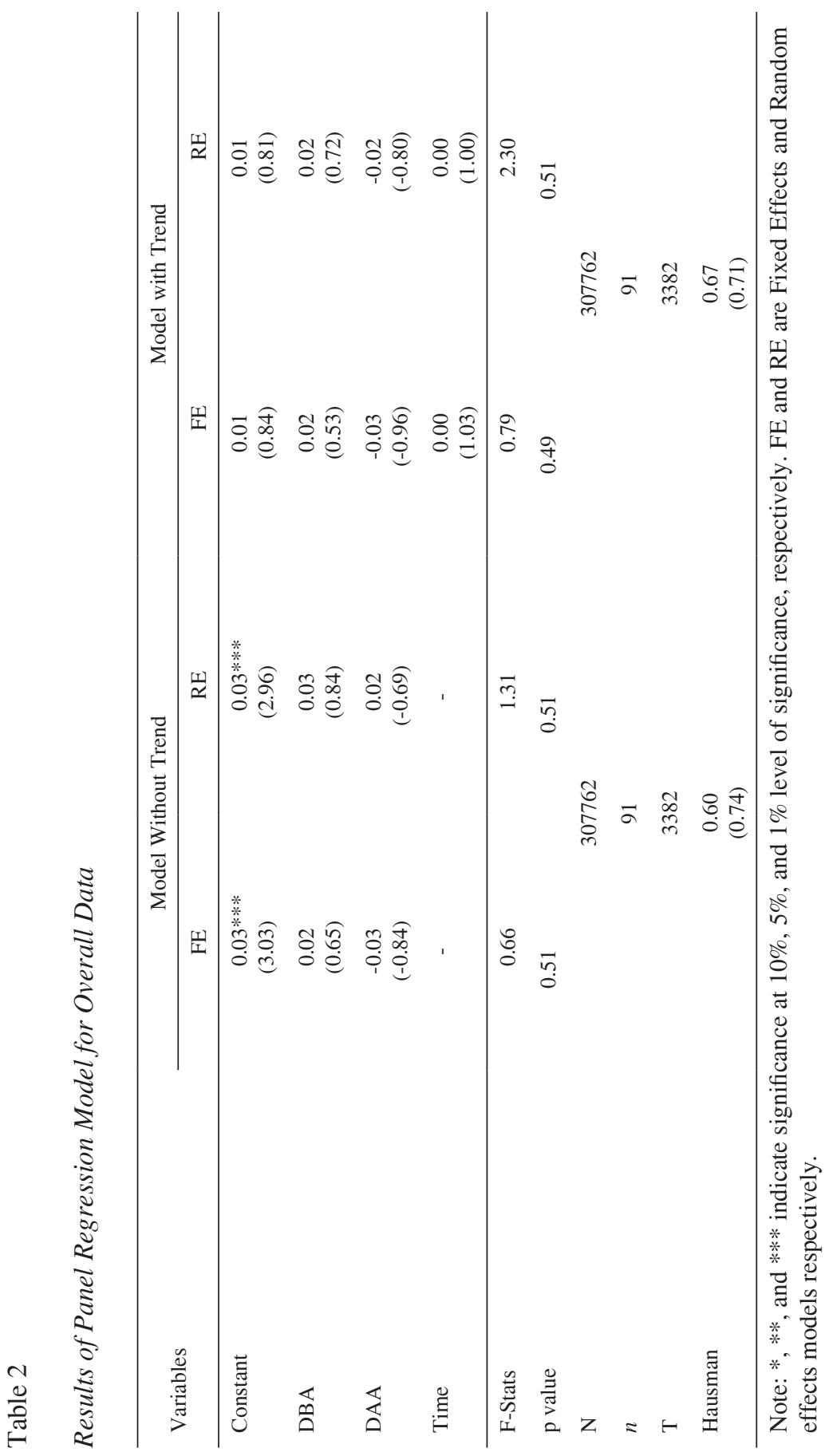


Malaysian Management Journal Vol. 23, December 2019 47-64

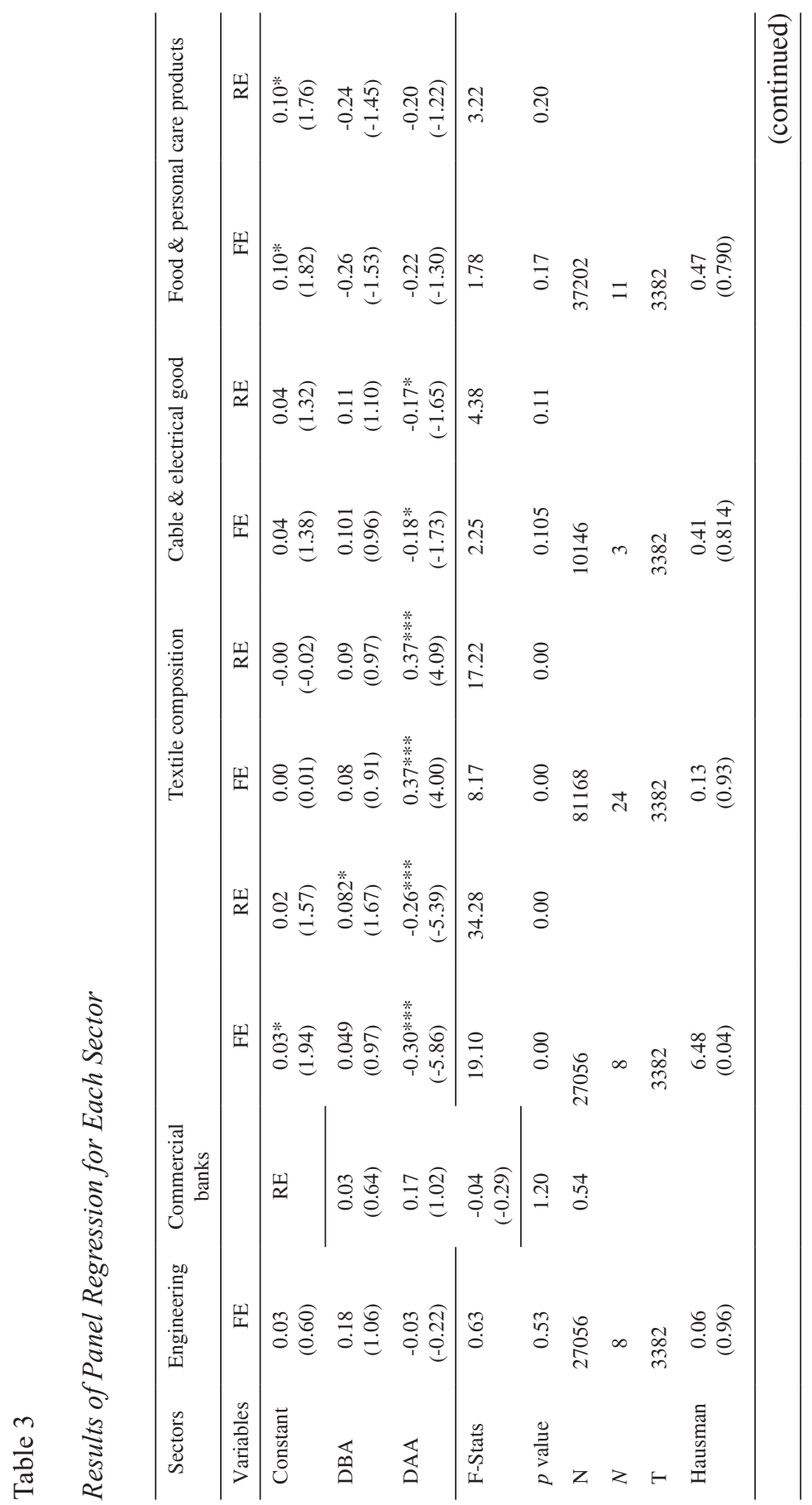


Malaysian Management Journal Vol. 23, December 2019 47-64

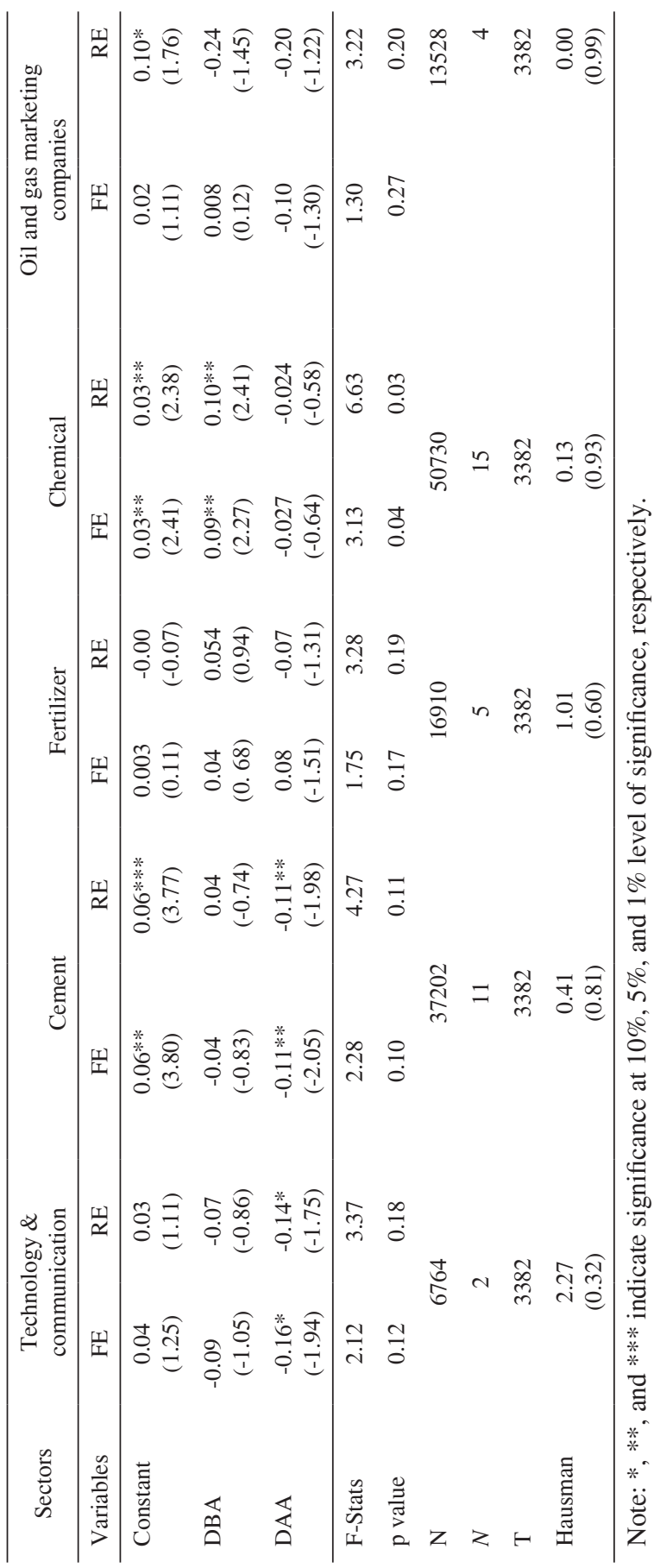




\section{Results of Event Study Methodology}

Table 4 depicts that the values of AAR are significant not only on the event day but also around the event in TEXT, FPCP and for the data of all sectors which disapproves the dividend irrelevance hypothesis and reveals the dominance of insider trading in PSX. Moreover, BANK, CAEG, and CMNT sectors have statistical meaningful values of AAR after the event date, which also proves that dividend announcements influence substantially to the stock returns. However, on the basis of AAR, it can be concluded that ENGR, TECH, FRTZ, and OGMC support dividend irrelevance theory.

Table

Results of Event Study Methodology for All Sectors

\begin{tabular}{|c|c|c|c|c|c|c|}
\hline \multirow[t]{2}{*}{ Sectors } & \multicolumn{3}{|c|}{ AAR } & \multicolumn{3}{|c|}{ CAAR 61 days } \\
\hline & $\begin{array}{c}\text { Before } \\
\text { event }\end{array}$ & $\begin{array}{l}\text { Event } \\
\text { Dday }\end{array}$ & $\begin{array}{l}\text { After } \\
\text { event }\end{array}$ & $\begin{array}{c}\text { Before } \\
\text { event }\end{array}$ & $\begin{array}{c}\text { Event } \\
\text { day }\end{array}$ & $\begin{array}{l}\text { After } \\
\text { event }\end{array}$ \\
\hline EMGR & No & No & No & Yes*** & Yes*** & Yes*** \\
\hline BANK & No & No & Yes* & No & No & No \\
\hline TEXT & Yes* & Yes** & Yes* & Yes* & No & Yes*** \\
\hline CAEG & No & No & Yes* & Yes** & Yes** $^{* *}$ & Yes** \\
\hline FPCP & Yes** & Yes** & Yes* & Yes** & No & No \\
\hline TECH & No & No & No & No & No & No \\
\hline CMNT & No & No & Yes* & No & No & Yes** \\
\hline FRTZ & No & No & No & Yes** & Yes* & Yes* \\
\hline CHEM & Yes* & No & No & Yes* & Yes* & Yes*** \\
\hline OGMC & No & No & No & No & No & No \\
\hline \multirow[t]{2}{*}{ All Sectors } & Yes** & Yes** & Yes* & No & No & Yes** \\
\hline & \multicolumn{3}{|c|}{ CAAR 31 Days } & \multicolumn{3}{|c|}{ CAAR 15 Days } \\
\hline EMGR & No & No & Yes*** & Yes*** & No & No \\
\hline BANK & No & Yes* & Yes*** & No & Yes* & Yes*** \\
\hline TEXT & No & Yes* & Yes* & Yes** & Yes** & Yes** \\
\hline CAEG & No & Yes** & Yes** & Yes** & Yes** & Yes* \\
\hline FPCP & Yes $^{* *}$ & No & No & Yes** & No & No \\
\hline TECH & Yes* & Yes** & Yes** & Yes* & No & No \\
\hline CMNT & No & No & Yes** & Yes* & Yes* & No \\
\hline FRTZ & Yes** & Yes*** & Yes*** & Yes** & No & No \\
\hline CHEM & No & No & Yes*** & No & No & Yes*** \\
\hline OGMC & Yes** & Yes*** & Yes*** & No & Yes* & Yes*** \\
\hline All Sectors & No & No & Yes* & Yes* & No & Yes* \\
\hline
\end{tabular}




\section{The Short Run and Long Run Analysis of AARs}

The values of AAR for 61 days' window can be used for the short term and long-term analysis. Table 5 shows the signs of AAR in the given time span around the events. Most of the calculated values of AAR before the event are positive and remain positive after the announcement until day 10. Similarly, the table also reveals that AAR turns to negative by the tenth day $(t=10)$ to onward days because of the possible ex-dividend or book closure date.

Moreover, on the dividend announcement date $(t=10)$, numerous sectors portray a positive sign with the values of average abnormal returns. This demonstrates that there are abundant chances for excess returns around the announcement date. This confirms the notion of semi-strong form of efficient market that the stock prices reflect all available information as well as the information which is not readily available to the public and can help the investors to surge their returns from the market average.

Table 5

Signs of Maximum Values of AARs for Short Run and Long Run Analysis

\begin{tabular}{lllllll}
\hline Sectors & -30 to -10 & -10 to 0 & t $=0$ & 0 to 10 & 10 to 20 & 20 to 30 \\
\hline ENGR & positive & positive & positive & positive & negative & negative \\
BANK & positive & positive & positive & positive & negative & negative \\
TEXT & positive & negative & negative & positive & negative & positive \\
CAEP & positive & positive & positive & positive & negative & negative \\
FPCP & positive & positive & positive & positive & negative & negative \\
TECH & positive & negative & negative & positive & negative & positive \\
CMNT & negative & positive & positive & negative & negative & negative \\
FRTZ & positive & positive & negative & positive & negative & negative \\
CHEM & positive & negative & positive & positive & negative & negative \\
OGMC & positive & positive & positive & positive & negative & positive \\
Overall & positive & negative & positive & positive & negative & negative \\
\hline
\end{tabular}

\section{Conclusion}

The dividend plan has found a significant place in the financial economics literature, however, the findings of literature are contrary to each other. The 
results of panel regression analysis reveal that some sectors have significant evidence of the market abuse in term of insider trading and have substantial relationships between the dividend declaration and stock prices. Similarly, the positive significant values of AAR, calculated from ESM, before the event indicate the notion of insider trade, whereas positive significant values of AAR after the event show that the stock market is a semi-strong efficient market and has arbitrage opportunities for high profit.

The results support information content hypothesis that assumes managers have more information than investors, which causes insider trading in Pakistan, and the dividend is a source of reducing asymmetric information among them. Moreover, the significant values of AAR around the event support semi-strong efficient hypothesis as the stock prices reflect currently available information like dividend announcements and information leakages.

By generalising the results, it clearly reveals that almost all sectors of PSX are facing the problem of insider trading. We should eliminate this whitecollar financial crime that is considered rampant in PSX. Investors are shy to take part in PSX and lose confidence due to this market abuse. It is a legal obligation of The Securities and Exchange Commission of Pakistan (SECP) to abolish the market abuse through proper regulations and their implementation. Section 15 of Securities and Exchange Ordinance 1969, which deals with this pecuniary misconduct, should be rationalised.

Moreover, to overcome this market abuse, SECP should create efficient surveillance wing through software with a huge database, provide exclusive recognising code for every client ${ }^{5}$, rationalise group accounts of stocks in the Central Depository System, eliminate off-system trades by stockbrokers and use the broad information-connection ${ }^{6}$. Additionally, in the meeting of the board of directors, when they decide for the dividend payments, they should announce the dividends on the meeting day rather than on the upcoming days. In this way, there is no asymmetric information that boosts the insider trading. Precisely, it is a teamwork of the stock exchange, whistleblowers, registered companies, and the SECP collectively detecting and punishing this white-collar financial crime. 


\section{References}

Abdullah, N. H., Rashid, R., \& Ibrahim, Y. (2002). The effect of dividend announcements on stock returns for companies listed on the main board of the Kuala Lumpur stock exchange. Malaysian Management Journal, 6(1\&2), 81-98.

Aharony, J., \& Swary, I. (1980). Quarterly dividend and earnings announcements and stockholders' returns: An empirical analysis. The Journal of Finance, 35(1), 1-12.

Ahmed, H., \& Javid, A. Y. (2008). Dynamics and determinants of dividend policy in Pakistan (evidence from Karachi stock exchange nonfinancial listed firms). Munich Personal RePEc Archive (Paper No. 37342). Retrieved from https://mpra.ub.uni-muenchen.de/37342/

Akbar, M., \& Baig, H. H. (2010). Reaction of stock prices to dividend announcements and market efficiency in Pakistan. The Lahore Journal of Economics, 15, 103-125.

Asquith, P., \& Mullins, D. W. (1983). The impact of initiating dividend payments on shareholders' wealth. The Journal of Business, 56(1), 77-96.

Baker, H. K. (2009). Residual dividend policy. In D. M. Smith. Dividends and dividend policy (pp. 115-126). New Jersey: John Wiley \& Sons.

Below, S. D., \& Johnson, K. H. (1996). An analysis of shareholder reaction to dividend announcements in bull and bear markets. Journal of Financial and Strategic Decisions, 9(3), 15-26.

Brown, S. J., \& Warner, J. B. (1980). Measuring security price performance. Journal of Financial Economics, 8(3), 205-258.

Campbell, J., \& MacKinlay, A. C. (1997). The econometrics of financial markets. Princeton: University Press.

Chaudhary, G. M., Hashmi S. H., \& Younis, A. (2016). Does Dividend announcement generate market signal? Evidence from Pakistan. International Journal of Economics and Financial Issues, 6(1), 65-72.

Gordon, M. J. (1963). Optimal investment and financing policy. The Journal of Finance, 18(2), 264-272.

Gunasekarage, A., \& Power, D. M. (2006). Anomalous evidence in dividend announcement effect. Managerial Finance, 32, 209-226.

Habibullah, M. S., \& Baharumshah, A. Z. (1999). Money supply, stock prices and the efficient market hypothesis: The case of Malaysia. Malaysian Management Journal, 3(1), 13-37.

Jahfer, A. (2016). Dividend policy and share price volatility: Evidence from Colombo stock market. International Journal of Managerial and Financial Accounting, 8(2), 97-108.

Kadıoğlu, E., Telçeken, N., \& Öcal, N. (2105). Market reaction to dividend announcement: Evidence from Turkish. International Business Research, 8(9), 83-94. 
Khan, K. I. (2012). Effect of dividends on stock prices-a case of chemical and pharmaceutical Industry of Pakistan. Management, 2(5), 141-148.

Khan, R. (2019). Effect of dividend on stock price in emerging stock market (Unpublished Report). School of Business and Economics, United International University.

Khurana, R., \& Warne, D. P. (2018). Stock price adjustments to selected corporate announcements: A study of dividend announcements. Asian Journal of Management, 9(1), 649-659.

Lintner, J. (1956). Distribution of incomes of corporations among dividends, retained earnings, and taxes. The American Economic Review, 46(2), 97-113.

Mahmood, S., Sheikh, M. F., \& Ghaffari, A. (2011). Dividend announcements and stock returns: An event study on Karachi stock exchange. Interdisciplinary Journal of Contemporary Research in Business, 3(8), 972-981.

Majanga, B. B. (2015). The dividend effect on stock price-an empirical analysis of Malawi listed companies. Accounting and Finance Research, 4(3), 99-105.

Mehndiratta, N., \& Gupta, S. (2010). Impact of dividend announcement on stock prices. International Journal of Information Technology and Knowledge Management. 2(2), 405-410.

Miller, M. H., \& Modigliani, F. (1961). Dividend policy, growth, and the valuation of shares. The Journal of Business, 34(4), 411-433.

Mukora, M. Y. W. (2013). The effect of dividend announcement on stock returns of firms listed at the Nairobi securities exchange (Unpublished MBA project), University of Nairobi.

Nazir, M. S., Nawaz, M. M., Anwar, W., \& Ahmed, F. (2010). Determinants of stock price volatility in Karachi stock exchange: The mediating role of corporate dividend policy. International Research Journal of Finance and Economics, 55(55), 100-107.

Ngoc, D. B., \& Cuong, N. C. (2016). Dividend announcement and exdividend effects on stock return. International Journal of Economics and Finance, 8(7), 207-215.

Nishat, M., \& Irfan, C. M. (2004). Dividend policy and stock price volatility in Pakistan. In Pide-19th Annual General Meeting and Conference.

Ozo, F. K., \& Arun, T. G. (2019). Stock market reaction to cash dividends: evidence from the Nigerian stock market. Managerial Finance, 45(3), 366-380.

Peterson, P. P. (1989). Event studies: A review of issues and methodology. Quarterly Journal of Business and Economics, 28(3), 36-66.

Poornima, B. G., Morudkar, V., \& Reddy, Y. V. (2019). Impact of dividend announcements of banks on stock returns and the determinants of dividend policy. Indian Journal of Finance, 13(5), 7-24. 
Pynnonen, S. (2005). On regression based event study. Acta Wasaensia, 143, 327-354.

Rajamohan, Dr. S., \& Muthukamu, M. (2014). Impact of selective corporate events on price movements of stocks of bank nifty index. Indian Journal of Applied Research, 4(4), 317-320.

Rosario, S., \& Chavali, K. (2016). Market reaction on dividend announcement in Oman: An event study methodology. International Journal of Economics and Financial Issues, 6(1), 103-108.

Saleh, W. (2007). Investors reaction to dividend announcements: Parametric versus nonparametric approach. Applied Financial Economics Letters, 3, 169-179.

Sanda, A. U., Shafie, A. G., \& Gupta, G. S. (1999). Behaviour of stock returns in the KLSE: A test of the random walk hypothesis. Malaysian Management Journal, 3(1), 71-91.

Sharif, T., Purohit, H., \& Pillai, R. (2015). Analysis of factors affecting share prices: The case of Bahrain Stock Exchange. International Journal of Economics and Finance, 7(3), 207-216.

Swarnalatha, C., \& Babu, K. S. (2017). Stock price reaction to dividend announcement on select banking stocks. Asian Journal of Research in Social Sciences and Humanities, 7(1), 1043-1058.

Uddin, M. N., \& Uddin, M. J. (2014). Dividend announcement of the commercial banks in DSE: Scenario and effect on stock price. International Journal of Ethics in Social Sciences, 2(1), 143-155.

Venkatesh, P. C. (1989). The impact of dividend initiation on the information content of earnings announcements and returns volatility. The Journal of Business, 62(2), 175-197.

\section{Endnotes}

1 The results of both estimated windows are identical. So, the study only discusses the outcomes of 300 days estimated windows.

2 Authors selected the top ten active sectors on 26-Oct-2017 from the website Pakistan Stock Exchange.

3 Only includes companies which announce the dividends in given date.

4 The results of panel regression analysis are only presented here for equation (8) because there is no significant difference between the results of equation (8) and equation (9).

5 This system has already been implemented in India.

6 This is used in Australia. 